Original Research Paper

\title{
Relationship Pattern of Soil and Water Quality in Sustaining Natural Feed Stocks and the Life of Milkfish, Chanos chanos (Forsskal, 1775): The Case study on a Traditional Pond in Kedungpeluk Village, Candi, Sidoarjo, East Java, Indonesia
}

\author{
${ }^{1}$ Muhammad Musa, ${ }^{1}$ Uun Yanuhar and ${ }^{2}$ Soemarno \\ ${ }^{I}$ Department of Aquatic Resources Management, University of Brawijaya, Malang, Indonesia \\ ${ }^{2}$ Departmentof Soil, University of Brawijaya, Malang, Indonesia
}

\author{
Article history \\ Received: 25-06-2015 \\ Revised: $1512-2015$ \\ Accepted: 23-02-2016 \\ Corresponding Author: \\ Muhammad Musa \\ Department of Aquatic \\ ResourcesManagement, \\ University of Brawijaya, Malang, \\ Indonesia \\ Email: musa_ub@yahoo.co.id
}

\begin{abstract}
Traditional aquaculture activities in Kedungpeluk are currently facing the problem of low Survival (SR) and slow growth. The purpose of this study is to examine the development of soil and water quality as well as the behavior of soil and water quality parameters, which act as a limiting factor and determinant of the quality of natural food and fish life during rearing. The study is descriptive and developmental. Data collection is done through longitudinal surveys. The results showed that the pond bottom soil is very acidic and anaerobic, whereas the water is alkaline and aerobic. There are indications of hydrolysis of $\mathrm{NH}_{4}$ bound to the mud to the water above it, changing $\mathrm{NH}_{4}$ into $\mathrm{NH}_{3}+\mathrm{H}^{+}$and, of decreasing the amount of oxygen as it is absorbed by the base layer of anaerobic soil because of the stirring by the milkfish in search of food. Natural feed quality has decreased because it is dominated by species of phytoplankton of Cyanophyta hated by the milkfish. The condition is considered a causative factor of low survival and slow growth.
\end{abstract}

Keywords: Soil and Water Quality, Phytoplankton, Natural Feed and Milfish

\section{Introduction}

Fish farms in Kedungpeluk are one of the regional development centers for pond arrangement in Sidoarjo, East Java, Indonesia. Fish farms in Kedungpeluk are mostly traditional ponds, major commodity cultivated is milkfish and the pond model is locally known as "Porong type" commonly applied by farmers in Sidoarjo. Milkfish aquaculture is very important in Indonesia, mainly for domestic consumption, the local economy and food security. Smoked milkfish and presto milkfish are two very popular local foods in the community. In addition, milkfish can be used as a fishing lure in fishing in the sea.

The milkfish aquaculture has been facing problems of slow growth and low production. A preliminary survey in 2010 in the village which is the center of milkfish aquaculture, Kedungpeluk, Sidoarjo, shows the size of juvenile reared for 4 months has become smaller-as $1 \mathrm{~kg}$ used to contain 4 to 5 fish, now it contains 6 to 7 fish.
Under normal conditions, juvenile aged 3 to 3.5 months can weigh until 250 grams (Masykur, 2009). Milkfish aquaculture technology applied is traditional and ponds are used continuously. According to Buwono (1993), the quality of the pond bottom usually decreases as time goes by. Carrying capacity of the pond also decreases due to load of organic material input, both from outside and from inside the pond.

In terms of fish farming in traditional ponds (extensive), sediment or soil base and water play an important role in growing natural feed and fish life. The success rate of fish farming in ponds is largely determined by the quality of base soil and water. Sediment is inseparable of the aquatic environment and its role is to determine the quality of aquatic environments. Sediment or base soil plays several roles including (1) demolishing organic material by bacteria, (2) as a regulator of water quality (DO, free $\mathrm{CO}_{2}, \mathrm{H}_{2} \mathrm{~S}$ ) and (3) determining the level of fertility of pond water (Andayani et al., 1994). 
Water, as the medium of fish life, has a direct effect on the health and growth of fish. The quality of water determines the existence of various types of organisms in the pond ecosystem, both for the cultivated organisms and other biota as a constituent of the pond ecosystem. Water quality far from optimal values may lead to failure of the cultivation. Good water quality is an absolute requirement of cultivation to produce high productivity. In terms of physics, chemistry and biology, water has several functions to support fish life and natural feed, as follows: (1) In terms of physics, water is a place to live and provide space for the fish; (2) in terms of chemistry, water acts as a carrier of nutrients elements, vitamins and other dissolved gases; and (3) in terms of biology, it is a good medium for biological activity as well as the formation and decomposition of organic matter.

This study examines the relationship pattern of soil and water quality in the preparation of natural feed to sustain fish life. The purpose of this study is to determine (1) the development of soil and water quality during cultivation and (2) the behavior of soil and water quality parameters, which acts as a limiting factor and determinant of the quality of natural feed and fish life.

\section{Research Methods}

The research took place in Kedungpeluk village, in one of the ponds, with the following considerations: (1) The fishpond is traditionally managed; (2) major commodity cultivated is milkfish; and (3) the pond model is locally known as "Porong type" commonly applied by farmers in Sidoarjo. This study was conducted in one cycle of cultivation, approximately for six months from January to June 2011, as shown in Appendix 1.

The study is descriptive and developmental. Descriptive study systematically describes the facts and characteristic of the following elements: Base soil and water, natural feed and properly cultivated fish. The developmental study is to determine the development of these elements and their interactions over a period of time. Data collection is done through longitudinal surveys i.e., the development of data collection is done through the process and timing of a number of samples observed or measured continuously every 2 weeks following the development period.

The method of measuring soil quality parameters is performed as follows: (1) Soil acidity $(\mathrm{pH})$ and (2) The redox potential (Eh). Prepare air-dried soil samples and distilled water with ratio of volume per volume of $1: 1$. Inserting into the film bottle, shake the soil solution by means of swinging by hand, as many as 15 times, measuring $\mathrm{pH}$ and Eh with use $\mathrm{pH}$ and Eh meter. (3) $\mathrm{C}$ organic. Soil samples size $<0.5 \mathrm{~mm}$ as much as $0.500 \mathrm{~g}$, put into volumetric flask $100 \mathrm{~mL}$. Added $5 \mathrm{~mL} \mathrm{~K}_{2} \mathrm{Cr}_{2} \mathrm{O}_{7}$ $1 \mathrm{~N}$, shaked, then added $7.5 \mathrm{~mL}$ of $\mathrm{H}_{2} \mathrm{SO}_{4}$ of concentrated, shaked and allowed to stand $30 \mathrm{~min}$. Diluted with water free of ion and allow to cool. The next day the measured of absorbance from clear solution, with spectrophotometer $\lambda 561 \mathrm{~nm}$. As a comparison was made standard 0 and $250 \mathrm{ppm}$, by pipette 0 and $5 \mathrm{~mL}$ from standard solution 5.000 ppm into a flask of $100 \mathrm{~mL}$ with the same treatment as workmanship of examples. (4) N total. Move qualitatively, the entire sample extracts into the boiling flask (used of water free of ion and pumpkin of spray). Adding a bit of powder boiling stone and distilled water until half the volume of the flask. Prepare a container for $\mathrm{NH}_{3}$ that were freed on erlenmeyer containing $10 \mathrm{~mL}$ of boric acid $1 \%$, plus 3 drops of indicator Conway and connected by tool of distillation. Added $10 \mathrm{~mL} \mathrm{NaOH} 40 \%$ into the boiling flask containing the sample and closed. Distilled to a volume of container: $50-75 \mathrm{~mL}$ (green color). Distillate titrated with $\mathrm{H}_{2} \mathrm{SO}_{4} 0.050 \mathrm{~N}$ until pink and noted titar sample volume (Vc) and blank (Vb). (6) P olsen. Inserted $1000 \mathrm{~g}$ of soil samples $<2 \mathrm{~mm}$, into the shake bottle, plus $20 \mathrm{~mL}$ extraction Olsen and shaken for 30 min. Strain and if the solution is still turbid, filtered again as before. Extract, taken $2 \mathrm{~mL}$ with pipette, put in a test tube and further along with the standard solution was added $10 \mathrm{~mL}$ phosphate dye reagents, shake until homogeneous and allowed during $30 \mathrm{~min}$. Absorbance of the solution was measured with a spectrophotometer $\lambda$ $693 \mathrm{~nm}$. (7) Measurement of $\mathrm{NH}_{4}^{+}$(cation exchange force) can be determined by the method of the Blue indofenol. Pipette $0.5 \mathrm{~mL}$ each perkolat $\mathrm{NaCl}$ and standard series $\mathrm{NH}_{4}{ }^{+}(0 ; 2.5 ; 5 ; 10 ; 15 ; 20$ and 25 me $\mathrm{L}^{-1}$ ) into a test tube. Each tube plus $9.5 \mathrm{~mL}$ of water free of ion (dilution $20 \mathrm{x}$ ). Pipette into another test tube each $2 \mathrm{~mL}$ of an aqueous extract and standard series. Added consecutive buffering solution Tartrate and Na-phenate respectively: $4 \mathrm{~mL}$, shake and let stand for $10 \mathrm{~min}$. Add $4 \mathrm{~mL}$ of $\mathrm{NaOCl} 5 \%$, shake and measured with a spectrophotometer $\lambda 636 \mathrm{~nm}$ after 10 min since the administration of these reagents. (8) $\mathrm{NH}_{4}{ }^{+}$. Inserted $20 \mathrm{~g}$ soil sample of finely $<2 \mathrm{~mm}$ into the shake bottle 100 $\mathrm{mL}$, add $1 \mathrm{~mL}$ of activated carbon and $40 \mathrm{~mL}$ extractors Morgan Wolf. Shake for 5 min with a shaker machine at minimum 180 wobble $\mathrm{min}^{-1}$. Filter with filter paper of Whatman \# 1, to obtain a clear extract. Pipette into test tubes each $2 \mathrm{~mL}$ of the extract sample and standard series. Adding consecutive: Tartrate buffering solution and Na-phenate each $4 \mathrm{~mL}$, shake and let stand for 10 min. Add $4 \mathrm{~mL} \mathrm{NaOCl} \mathrm{5 \% ,} \mathrm{shake} \mathrm{and} \mathrm{measured} \mathrm{with} \mathrm{a}$ spectrophotometer $\lambda 636 \mathrm{~nm}$ after $10 \mathrm{~min}$ since the administration of these reagents. (9) $\mathrm{NO}_{3}$. Pipette each 5 $\mathrm{mL}$ extract sample and standard series into a test tube. 
Added consecutive brucine solution of 0.5 and $5 \mathrm{~mL}$ $\mathrm{H}_{2} \mathrm{SO}_{4}$ of concentrated (p.a.), he whipped until homogeneous and allowed $30 \mathrm{~min}$. The solution is measured with a spectrophotometer $\lambda 432 \mathrm{~nm}$.

The method of measuring water quality parameters is performed as follows: (1) Brightness. Secchi disc is inserted into the water up to the limit visible and note its depth. Slowly, secchi disc pulled back to be seen again and note its depth. The average of the two readings is the brightness value. (2) Temperature. Thermometer $\mathrm{Hg}$ dipped in water, allowed during for some time and read the temperature designated by $\mathrm{Hg}$ (temperature readings, the thermometer still in the water). (3) $\mathrm{pH}$. Before the $\mathrm{pH}$ meter is used, calibrated with buffer solutions $\mathrm{pH} \mathrm{4,} 7$ and 9. The electrode was washed with distilled water, dried with tissue, put in a water sample, allowed during for some time (stable value) and recorded value of $\mathrm{pH}$. (4) DO. Taking water samples with BOD bottles using "Kemmerer water sampler", so there is no contact with air. The sample in the BOD bottles are given $1 \mathrm{~mL}$ of $\mathrm{KI}$ alkali and $1 \mathrm{~mL} \mathrm{MnSO}_{4}$, stirred by flipping through the bottle until homogeneous and allowed to precipitates. Most of the water samples were clear upper discarded, given $2 \mathrm{~mL}$ $\mathrm{H}_{2} \mathrm{SO}_{4}$ of concentrated and stirred until the precipitate dissolved. Titration immediately with $\mathrm{Na}_{2} \mathrm{~S}_{2} \mathrm{O}_{3}$ until the color changes from brown to yellow, was given 1-2 drops of starch, titration again until the blue color disappeared. Record the volume of titrant used. (5) free $\mathrm{CO} 2.50 \mathrm{~mL}$ water sample in Erlenmeyer given PP indicator with a pipette, stirring and when no color means it contains free $\mathrm{CO}_{2}$ gas. Titration with $\mathrm{Na}_{2} \mathrm{CO}_{3}$ $0.0227 \mathrm{~N}$ until it turns pink and record the volume of titrant used. (6) TOM. $25 \mathrm{~mL}$ water sample was given $0.5 \mathrm{~mL}$ of $\mathrm{H}_{2} \mathrm{SO}_{4} 6 \mathrm{~N}$ and a few drops of $\mathrm{KMnO}_{4} 0.01$ $\mathrm{N}$ until the solution is pink and given again of solution $10 \mathrm{~mL} \mathrm{KMnO}_{4} 0.01 \mathrm{~N}$ until the color becomes red. The solution is heated in the flask erlenmeyer during 10 min. The solution was appointed and allowed of the temperature to drop $80^{\circ} \mathrm{C}$, was given $10 \mathrm{~mL}$ oxalic acid $0.01 \mathrm{~N}$ and the solution became colorless. In a fixed temperature of $70-80^{\circ} \mathrm{C}$, the solution was titrated with $\mathrm{KMnO}_{4} \quad$ 0:01 $\mathrm{N}$ until color becomes pink usage of $\mathrm{KMnO}_{4} 0.01 \mathrm{~N}$ as a measure of the amount of organic material that is soluble in water. (7) Ammonia. Water samples were filtered with Whatman paper No. 42. Taken $25 \mathrm{~mL}$ samples of filtered water and put in a 50 $\mathrm{mL}$ beaker make the standard solution with a concentration of $0.1 ; 0: 25 ; 0: 50 ; 0.75$ and $1.0 \mathrm{ppm} \mathrm{N}$ as $\mathrm{NH}_{4}^{+}$. Water samples and standard solution were each given Nessler and shake until evenly distributed. The solution is measured with a spectrophotometer $\lambda 430 \mathrm{~nm}$. (8) Nitrate. Taking $5 \mathrm{~mL}$ sample of water that has been filtered, put in a $50 \mathrm{~mL}$ beaker, added $0.5 \mathrm{~mL}$ brucine solution and $5 \mathrm{ml} \mathrm{H}_{2} \mathrm{SO}_{4}$ of concentrated. Stirred and allowed to stand during $15 \mathrm{~min}$. Make the standard solution Nitrate $0.75 ; 0.5 ; 0.25 ; 0.10 ; 0.05$ and 0.025 ppm $\mathrm{N}$ as Nitrate. Benchmarking is done with spectrophotometer $\lambda 410 \mathrm{~nm}$. (9) Orthophosphate. Take $50 \mathrm{~mL}$ of water sample and put in a beaker $100 \mathrm{~mL}$. Make phosphate standard solution with a concentration of $0.025 ; 0.05 ; 0.10 ; 0.25 ; 0.50 ; 0.75$ and $1.00 \mathrm{ppm}$ P. The water sample and the standard solution of $P$ each plus $2 \mathrm{ml}$ ammonium molybdate-sulfuric acid and stirred until uniform. Be given 5 drops of $\mathrm{SnCl}_{2}$ and shaked until the resulting blue color of his sharpness comparable to concentrations of phosphorus levels. Comparisons were made with the spectrophotometer $\lambda 690 \mathrm{~nm}$. (10) Salinity, Opening glass handrefractometer and wash with distilled water. Drops water samples in glass of handrefractometer. Handrefraktometer binoculars towards the light source and record the salinity value.

Summary of methods and tools as well as the references used in the determination of the main parameters: Soil quality, water quality and natural food is presented in Appendix 2. Specific phytoplankton sampling is done by filtering as much as 10 liters of water with plankton nets Number 25. Phytoplankton observations and calculations are performed with microscope and Sedgwick Rafter Counting Chamber (SRC). Observation of the predicted condition of fish is done at the time of harvest.

\section{Results and Discussion}

\section{Soil Quality}

Soil was taken at the beginning and end of cultivation cycle with consideration that changes in soil quality would be much longer than the water quality. Each plot was represented by one composite sample taken at some points considered representatives. The results of observation of soil quality are shown in Table 1.

From the table, it can be seen that during cultivation soil was very acidic, redox potential was negative (anaerobic), while organic $\mathrm{C}$, total $\mathrm{N}$ and $\mathrm{C} / \mathrm{N}$ ratio is categorized as moderate. In acidic soil, nitrate tends to sequestered by the soil colloids, ammonium $\left(\mathrm{NH}_{4}^{+}\right)$is dominant and phosphate retention occurs due to the reaction of phosphate by $\mathrm{Fe}, \mathrm{Al}$ and oxide hydrates (Soemarno, 2011). According to Boyd (1982), most of the phosphorus entering the ponds is bound by the soil and small amount becomes water-soluble fraction. Based on the value of $\mathrm{CV}$, there are several parameters of soil quality namely $\mathrm{C} / \mathrm{N}$ ratio, $\mathrm{P}$ Olsen (available), $\mathrm{NH}_{4}{ }^{+}$and varied nitrate. Patel and Shiyan (2001) confirm that a benchmark (critical limit) for $\mathrm{CV}$ based on a large number of experiments conducted at different times is $33 \%$. This means that changes in organic matter and soil nutrient are varied and unstable. 
Table 1. Quality of soil at the beginning and end of cultivation cycle

\begin{tabular}{|c|c|c|c|c|c|c|c|}
\hline No. & Parameter & $\mathrm{N}$ & Min. & Max. & Mean & $\begin{array}{l}\text { Standard } \\
\text { deviation }\end{array}$ & $\begin{array}{l}\text { Coefficient } \\
\text { variation }\end{array}$ \\
\hline 1 & $\mathrm{pH}$ & 6 & 4.00 & 4.60 & 4.333333 & 0.2338090 & 5.3955932 \\
\hline 2 & Redox potential $(\mathrm{mV})$ & 6 & -124.00 & -86.00 & -99.000000 & 14.1279860 & -14.2706900 \\
\hline 3 & C organic $(\%)$ & 6 & 2.24 & 4.07 & 2.775000 & 0.6678847 & 24.0679180 \\
\hline 4 & N Total $(\%)$ & 6 & 0.20 & 0.34 & 0.270000 & 0.0513809 & 19.0299740 \\
\hline 5 & $\mathrm{C} / \mathrm{N}$ ratio & 6 & 7.68 & 20.35 & 10.881670 & 4.7803406 & 43.9302250 \\
\hline 6 & P Olsen $\left(\mathrm{mg} \mathrm{kg}^{-1}\right)$ & 6 & 9.85 & 49.84 & 24.810000 & 14.7827750 & 59.5839380 \\
\hline 7 & KTK (me/100 g) & 6 & 47.50 & 58.54 & 52.030000 & 3.9444645 & 7.5811349 \\
\hline 8 & $\mathrm{NH}_{4}\left(\mathrm{mg} \mathrm{kg}^{-1}\right)$ & 6 & 28.50 & 74.25 & 47.263330 & 15.9072090 & 33.6565540 \\
\hline 9 & $\mathrm{NO}_{3}\left(\mathrm{mg} \mathrm{kg}^{-1}\right)$ & 6 & 26.73 & 77.83 & 49.543330 & 18.0752280 & 36.4836740 \\
\hline
\end{tabular}

Table 2. Quality of water at the beginning and end of cultivation cycle

\begin{tabular}{lllllll}
\hline Parameter & $\mathrm{N}$ & $\mathrm{Min}$ & $\mathrm{Max}$ & Average & STDEV & $\mathrm{CV}$ \\
\hline Temperature $\left({ }^{\circ} \mathrm{C}\right)$ & 13 & 29.67 & 33.67 & 31.83153846 & 1.430651636 & 4.494447032 \\
Light $(\mathrm{Cm})$ & 13 & 16.5 & 29 & 24.03846154 & 4.259604532 & 17.71995485 \\
$\mathrm{pH}$ & 13 & 7.53 & 10.03 & 8.855384615 & 0.91045424 & 10.28136303 \\
$\mathrm{DO}(\mathrm{ppm})$ & 13 & 6.82 & 11.71 & 9.543076923 & 1.373088882 & 14.38832457 \\
$\mathrm{CO}_{2}(\mathrm{ppm})$ & 13 & - & - & - & - & - \\
$\mathrm{TOM}(\mathrm{ppm})$ & 13 & 3.16 & 36.66 & 13.07923077 & 9.995403495 & 76.42195226 \\
Ammonia $(\mathrm{ppm})$ & 13 & 0 & 3.32 & 0.656923077 & 0.959065384 & 145.9935596 \\
Salinity $(\%)$ & 13 & - & - & - & - & - \\
Nitrate $(\mathrm{ppm})$ & 13 & 0.97 & 2.86 & 1.76 & 0.541956333 & 30.79297345 \\
Orthophosphate $(\mathrm{ppm})$ & 13 & 0.04 & 0.15 & 0.094615385 & 0.037330815 & 39.45533286 \\
\hline
\end{tabular}

\section{Water Quality}

Water sample was taken once in 2 weeks as many as 8 times (during cultivation) following the time change of the water. Each plot was represented by one composite sample taken at some point considered representative. The results of observation of water quality are shown in Table 2.

Ammonia amount at some time exceed the maximum limit of quality standards established. Ammonia in the research farm ranged from 0 to $3.32 \mathrm{ppm}$ with an average of $0.66 \mathrm{ppm}$. According to the Regulation Number $82 / 2001$, the limit of ammonia compounds in water is 0.5 $\mathrm{ppm}$. Nitrate concentrations ranged from 0.66 to $2.86 \mathrm{ppm}$ with an average of 1,689 ppm and orthophosphate ranged from 0.04 to $0.3 \mathrm{ppm}$ with an average of $0.096 \mathrm{ppm}$. Fertility of water viewed from $\mathrm{N}$ (nitrate) is at mesotrophic level and $\mathrm{P}$ (orthophosphate) is eutrophic According to Wetzel (1975), nitrates $>1-5 \mathrm{ppm}$ is mesotrophic and orthophosphate of 0.031 to $0.100 \mathrm{ppm}$ is eutrophic. According Welch and Lindeel (1980), P nutrient is a key parameter in determining the fertility of waters, as compared to $\mathrm{N}$; therefore, the condition of water in the category eutrophic is also characterized by a high $\mathrm{DO}$ and $\mathrm{pH}$ and low light and low $\mathrm{CO}_{2}$. Dissolved Oxygen (DO) ranged from 5.59 to $12.81 \mathrm{ppm}$ with a mean of $9.56 \mathrm{ppm}$, light ranged from 15 to $29 \mathrm{~cm}$ with an average of $23.624 \mathrm{~cm}$ and $\mathrm{pH}$ ranged from 7.5 to 10.03 , with an average of 8.85 . Furthermore, the low salinity concentration indicates fresh waters. Based on the CV value, there are several water quality parameters, namely
TOM, ammonia and orthophosphate. Patel and Shiyan (2001) confirm that a benchmark (critical limit) for CV based on a large number of experiments conducted at different times is $33 \%$. The ponds have eutrophic conditions, are unstable and contaminated.

\section{The Abundance and Composition of Natural Feed Phytoplankton}

Phytoplankton samples were taken following the observation of sampling for water quality. The observation of phytoplankton in the juvenile and semi-adult pond is shown in Fig. 1 and in adult pond is shown in Fig. 2.

Phytoplankton is a biological parameter that can be used as an indicator to evaluate the quality and level of fertility of the water. Changes to water quality and fertility rate are closely related to water potential in terms of abundance and composition of phytoplankton (Ferianita et al., 2005). Cyanophyta or Cyanobacteria dominate phytoplankton found in ponds during cultivation. Cyanobacteria are unicellular, live in colony and have the shape of a filament. Each individual cell generally has a thick cell wall and is covered by mucus, flexible and gram negative. When ingested, these cell types are difficult to digest (Segner et al., 1987) and can be toxic to fish (Bhaskar and Rao, 1990; Villaluz and Unggui, 1983). The fertility rate based on the abundance of phytoplankton found is eutrophic (in juvenile and semi-adult ponds of 2,204,982.00-30,500,606 individual $/ \mathrm{ml}$ and in the adult pond of 2,284,796-33,823,049 individual $/ \mathrm{ml}$ ). According to Landner (1976), the abundance of phytoplankton 0- 
2000 individual $/ \mathrm{ml}$ belongs to oligotrophic, 2000-15000 individual $/ \mathrm{ml}$ belongs to mesotrophic and more than $15000 \mathrm{individual} / \mathrm{ml}$ belongs to eutrophic.

\section{Milkfish Condition}

Fish seed reared in pond with a stocking density of 2 rean $(10,000$ head $) / 20,500 \mathrm{~m}^{2}$ or about 5000 head/ha, the cultivation period is 3 months and the productivity is 6,056 fish weighing $367 \mathrm{~kg}$. The results of mathematical calculations show that Survival (SR) was only $60.56 \%$ and $1 \mathrm{~kg}$ contained about 16 to 17 fish. In the business scale, this SR is relatively low and larger size describes slow growth of fish. According to Masykur (2009), under normal conditions on aquaculture, juvenile aged 3-3.5 months, can reach a size of 250 grams of individual fish.

\section{Soil and Water Quality in Sustaining Natural Feed Stocks and the Life of Milkfish}

Base soil of the ponds in Kedungpeluk that is very acid and anaerobic is inversely proportional to the water on it that is alkaline and aerobic. This can occur because of the changes of water and the relatively fertile water that irrigates the pond. The presence of a compound of carbon dioxide from the organic material on the pond bottom and nutrients, especially phosphorus in the pond water with high temperature and light, will also trigger the growth of phytoplankton of algae types, Cyanophyta, that can specifically bind nitrogen from the air faster. This will lead to the upper water column bases to be alkaline and aerobic because of the high activity of the photosynthetic process, while the water column below is an interface layer of both conditions. This condition has occurred on the research farm, characterized by the predominance of Cyanophyta and high photosynthetic activity (due to the low $\mathrm{CO}_{2}$ ). Such circumstances are not good for the life of the farmed fish as phytoplankton growing rapidly is not a natural food of fish; nutrients depletion may happen as fish relies solely on nutrients from water as the base soil is very acid and anaerobic.
According to Hanafi (2008), on acid soils, phosphorus nutrients cannot be utilized as they are bound by the element of $\mathrm{Al}$ and Fe. The impact is mass mortality of phytoplankton and threat to the life of fish. This is reinforced by the FAO (2012) stating that fish pond which is always flooded with water or in which water is difficult to flow out throughout the year in the tropics wet (in the tropics with high rainfall) with warm water and a high light provides excellent possibilities for fish farming. However, in the absence of proper environmental management, overall nutrient deficiency in fertile water may occur, although it has a very high production potential. This is because the pond bottom soil has very high levels of organic nutrients in conditions almost locked up and not used because of the nature of the anaerobic pond bottom. It is indicated to have occurred in adult ponds, where the nutrients in the water column on day 70 of cultivation has been reduced or discharged, while the pond bottom cannot provide nutrients because it is very sour and anaerobic. The process of phytoplankton death has occurred, marked by the abundance of phytoplankton were low (Fig. 2).

Furthermore, NH4 accumulation at the base soil that is very acidic and alkaline water (high $\mathrm{pH}$ ) would be very harmful to fish life. It can be seen that the pond bottom soil stirred by the fish in search of food at the base, NH4 in alkaline water will be hydrolyzed to $\mathrm{NH}_{3}$ and $\mathrm{H}+$ ions. $\mathrm{NH}_{3}$ resulted depends on the extent of alkaline water can affect soil $\mathrm{pH}$. Likewise, the anaerobic base soil when mixed with water will lead to dramatic decrease on the availability of oxygen in the water as it is absorbed by the soil. A high level of reduction occurs on farms that have been used for long and haven not gone through reclamation after harvest (Jaya et al., 1994). Salinity of the ponds studied was found to be low or it can be said as fresh waters. Subsequent impact of high ammonia concentration will lead to the formation of free $\mathrm{NH}_{3}-\mathrm{N}$ that is toxic to fish, especially at low salinity or fresh water with a high temperature and $\mathrm{pH}$ (Boyd and Tucker, 1998).

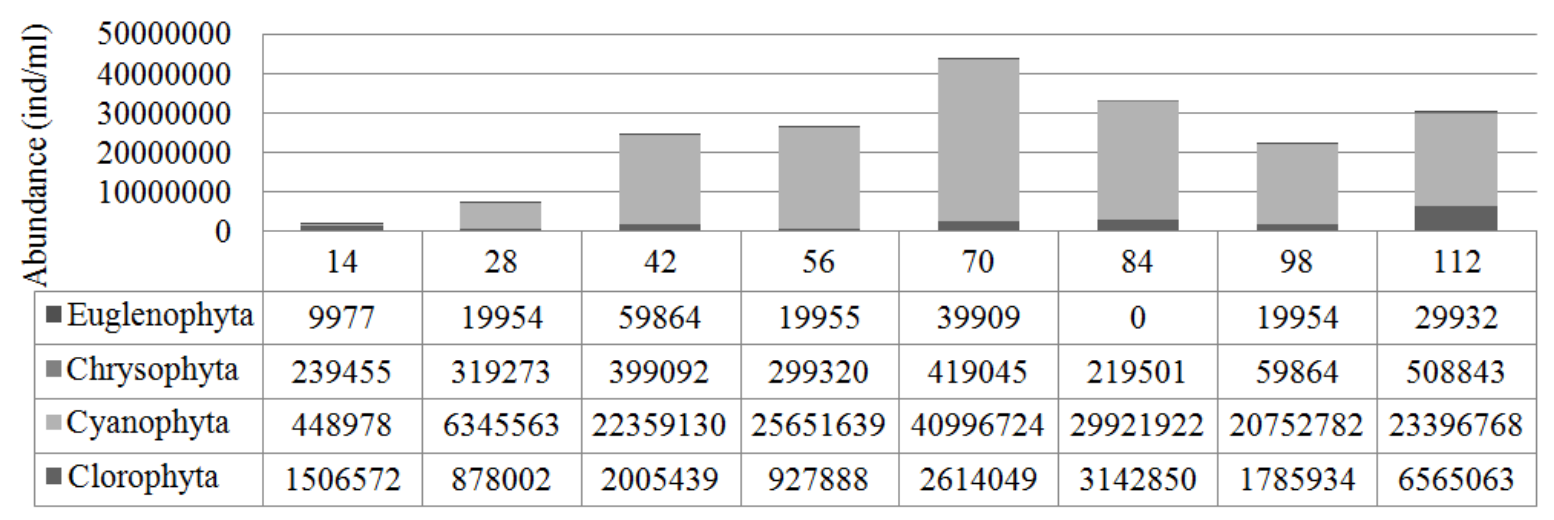

Fig. 1. Phytoplankton in the juvenile and semi-adult pond during cultivation 


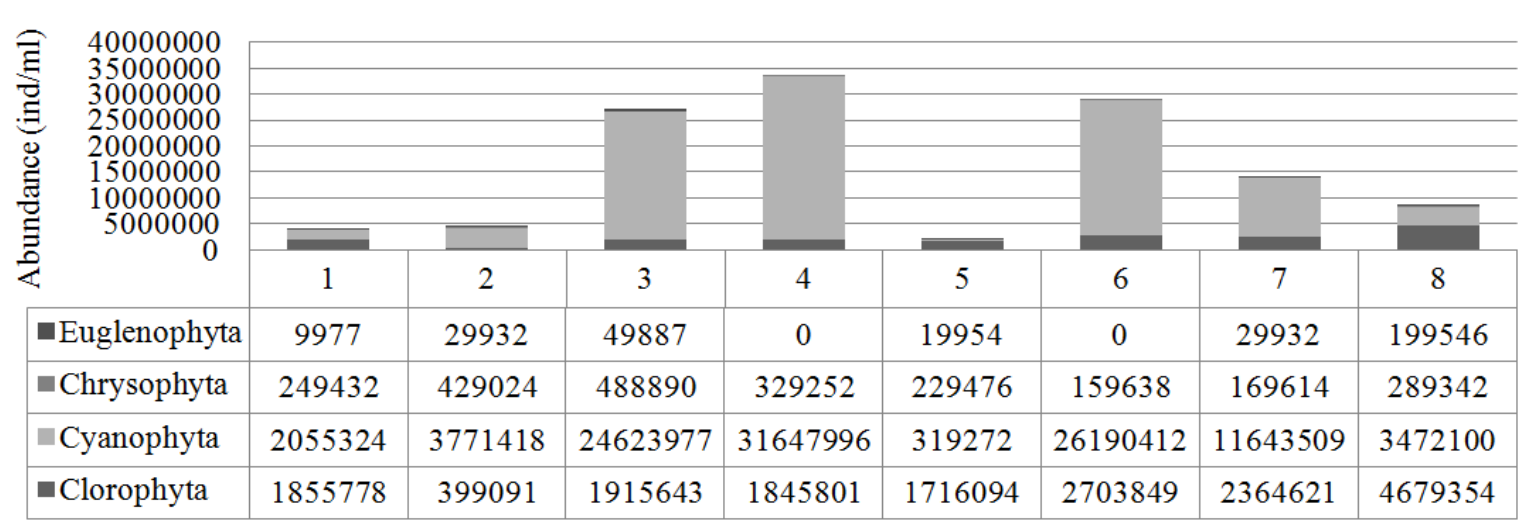

Fig. 2. Phytoplankton in the adult pond during cultivation

\section{Conclusion}

Based on the results of the study, some conclusions can now be drawn. The interface layer on ponds can occur because the base soil is acidic and anaerobic, while the water on top of it is alkaline and aerobic (due to the fertile water). Phytoplankton that grows in such waters is dominated by Cyanophyt, which is not natural feed for the fish and mass death will occur at the time of depleted nutrients because the soil is acidic and anaerobic. Further accumulation of $\mathrm{NH}_{4}$ on acid and anaerobic soils stirred by the water on top of it, which is alkaline, leads to hydrolysis of $\mathrm{NH}_{4}$ that changes it into $\mathrm{NH}_{3}$ and $\mathrm{H}^{+}$ions. Likewise, oxygen will drop dramatically as it is absorbed by the anaerobic soil. The condition is considered a causative factor for low SR and slow growing of fish.

\section{Acknowledgement}

Thank you submitted to prof. Soemarno and Dr. Uun Yanuhar above guidance, advice and criticism in the improvement of this paper. For publishing this paper, supported by the University of Brawijaya through Competitive Research Grant Program to increase the capacity of a lecturer from 2015 to 2016.

\section{Author's Contributions}

Muhammad Musa: A substantial contribution to the concept and design, data collection, interpretation and preparation for writing this article.

Soemarno: Supervisor for experimentation and methodologies, to help provide guidance for data collection and interpretation, preparation of articles and reviews.

UunYanuhari: Helping the analysis and interpretation of data, critical review of research for significant intellectual content and clarity of data, results and discussion are used for this article.

\section{Ethics}

This article is the original research and not yet published. The team of authors have read and approved the manuscript and there are no ethical issues involved.

\section{References}

Andayani, S., Purwohadijanto, P. Sunardi, Sulistiawaty and A. Supriyanto, 1994. Studies of soil fertility analysis ponds in Sidoarjo. Scientific Bulletin Fisheries.

APHA, 1985. Standard methods for examination of water and wastewater. American Public Health Association, Washington, DC.

Bhaskar, B.R. and K.S. Rao, 1990. Use of haematological parameters as diagnostic tools in determining the health of milkfish, Chanos chanos (Forsskal), in brackishwater culture. Aquaculture Res., 21: 125-130.

DOI: $10.1111 /$ j.1365-2109.1990.tb00387.x

Boyd, C.E., 1982. Water Quality Management for Pond Fish Culture. 1st Edn., Elsevier Scientific Publishing Company, Amsterdam, Netherlands, ISBN-10: 0444420541, pp: 318.

Boyd, C.E. and C.S. Tucker, 1998. Pond Aquaculture Water Quality Management. 1st Edn., Springer Science and Business Media, Boston, ISBN-10: 0412071819, pp: 700.

Buwono, I.D., 1993. Tiger shrimp ponds, systems of management patterned intensive. Canisius. Yogyakarta.

Davis, C.C., 1955. The Marine and Fresh-Water Plankton. 1st Edn., Michigan State University Press, pp: 562.

FAO, 2012. The state of world fisheries and aquaculture. FAO Fisheries and Aquaculture Department, Rome.

Ferianita, M., H. Haeruman and L.C. Sitepu, 2005. The phytoplankton community as a bio-indicator of the quality of the waters of Jakarta Bay. Faculty of Mathematics, University of Indonesia. 
Hanafi, A. 2008. Utilization Pond acid sulfate soils for Seaweed Cultivation (gracillariaverrucosa). Research Institute of Coastal Fisheries.

Jaya, I.B.M., S. Utaminingsih and Herminingsih, 1994. Guidelines for the analysis of water quality and sediment of brackish waters. The Directorate General of Fisheries, Aquaculture Centres brackish water.

Landner, L., 1976. Eutophication of lakes. World Health Organization Regional Office for Europe.

Masykur, M.F., 2009. The quality and productivity of milkfish cultivation in Central Java down. PT Jurnalindo Script Graphic.

Needham, J.G. and P.R. Needham, 1969. Fresh Water Biology. 1st Edn., Holden. Day, Inc., San Francisco, pp: 108.

Patel, N.M. and R.L. Shiyani, 2001. Coefficient of variation in field experiments and yardstick thereofAn empirical study. Curr. Sci., 81: 1163-1164.

Saeni, S.M. and L.K. Darusman, 1989. Practical Environmental Chemistry. 2nd Edn., IPB, Bogor, pp: 62.

Segner, H., P. Burkhardt, E.M. Avila, V. Storch and J.V. Juario, 1987. Effects of chlorella-feeding on larval milkfish, Chanos chanos, as evidenced by histological monitoring. Aquaculture, 67: 113-116. DOI: $10.1016 / 0044-8486(87) 90015-9$
Soemarno, 2011. Factors nutrient availability in the soil. Courses of study materials fertilizers and fertilization. Soil Department, Faculty of Agriculture UB.

Sulaiman, Soeparto and Eviati, 2005. Technical guidelines for chemical analysis of soil, plant, water and fertilizer. Institute of Soil Research. Agency for Agricultural Research and Development.

Swingle, H.S., 1969. Methods of analysis for water organic matter and pond bottom soils. Auburn University Auburn Ala.

Villaluz, A.C. and A. Unggui, 1983. Effects of temperature on behavior, growth, development and survival in young milkfish, Chanos chanos (Forskal). Aquaculture, 35: 321-330. DOI: 10.1016/0044-8486(83)90104-7

Ward, H.B. and G.C. Whipple, 1959. Myxophyceae, Algae and Bacillariophyceae. In: Fresh Water Biology, Edmonson (Ed.), John Wiley and Sons, Inc. New York, p: 95-189.

Welch, E.B. and T. Lindeel, 1980. Ecological Effects of Waste Water. 1st Edn., Cambridge University Press, ISBN-10: 0521224950, pp: 337.

Wetzel, R.G., 1975. Limnology. 1st Edn., W.B. Saunders Compeny, Philadelphia, pp: 743.

Wisnuprapto, 1987. Guidelines lab: Analysis of material contamination in the water. University Centre of Biotechnology. Bandung Institute of Technology.

\section{Appendix 1.}

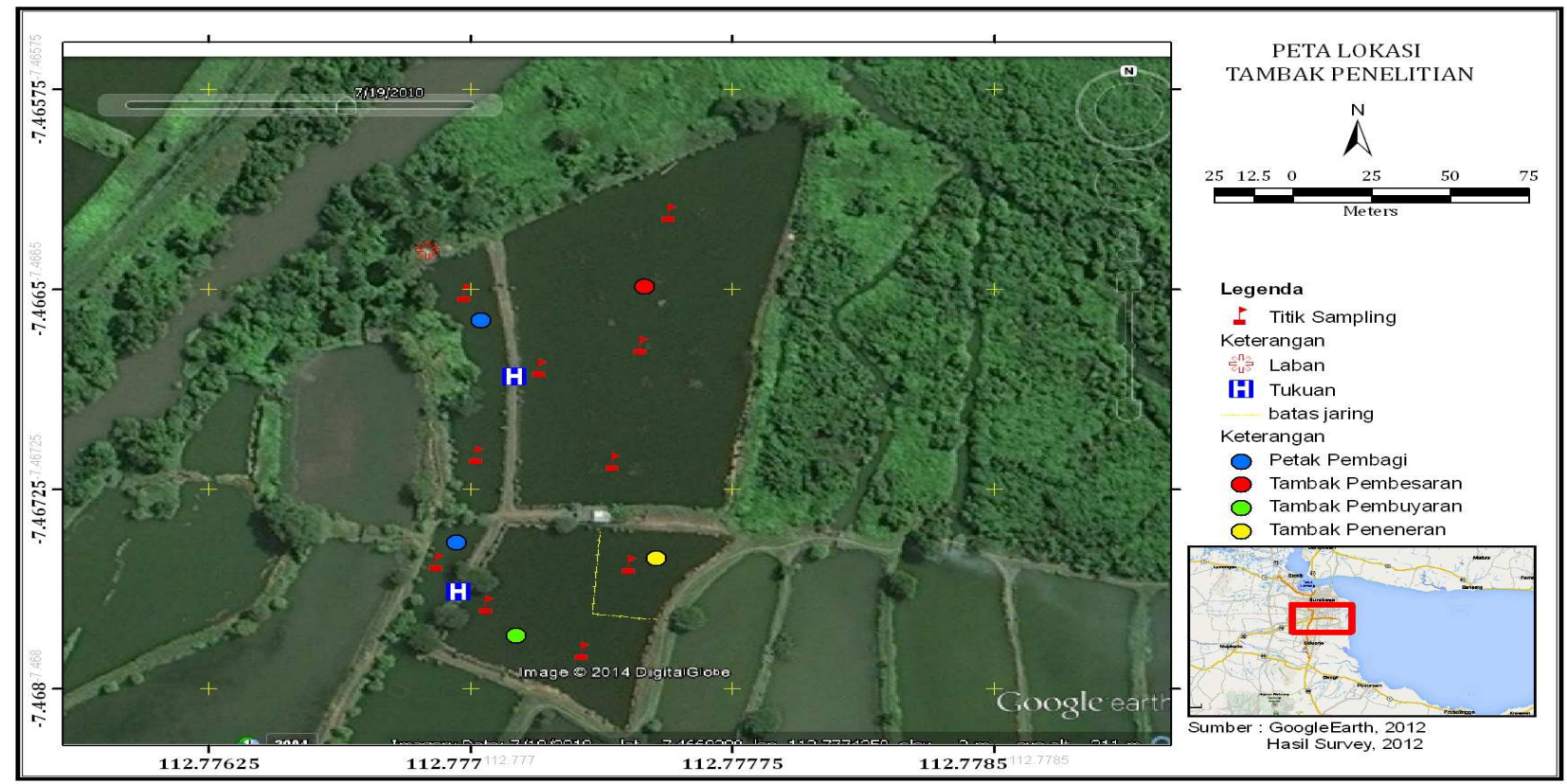




\section{Appendix 2.}

Water quality

\begin{tabular}{|c|c|c|c|}
\hline No & Parameter & Methods* and Tools ** & Source library \\
\hline 1. & Light $(\mathrm{Cm})$ & Secchi disc $* *$ & Jaya et al. (1994) \\
\hline 2. & Temperature (0C) & Termometer $\mathrm{Hg} * *$ & Jaya et al. (1994) \\
\hline 3. & $\mathrm{pH}$ & pH meter** & Jaya et al. (1994) \\
\hline 4. & $\mathrm{DO}(\mathrm{ppm})$ & Winkler titimetri* & Wisnuprapto (1987) \\
\hline 5. & $\mathrm{CO} 2(\mathrm{ppm})$ & Karbonattitimetri* & Saeni and Darusman (1989) \\
\hline 6. & TOM (ppm) & Permanganometri & Saeni and Darusman (1989) \\
\hline 7. & Ammonia (ppm) & Ammonium Chlorida* & Swingle (1969) \\
\hline 8. & Salinity $(\%)$ & Refraktometer** & Jaya et al. (1994) \\
\hline 9. & Nitrate (ppm) & Brusin* & Saeni and Darusman (1989) \\
\hline 10. & Orthophosphate (ppm) & Ammonium molibdatasamsulfat** & Swingle (1969) \\
\hline \multicolumn{4}{|c|}{ Soil quality } \\
\hline 1. & $\mathrm{pH}$ & Soil tester** & Sulaiman et al. (2005) \\
\hline 2. & Redox potential (mV) & Milivoltmeter** & Jaya et al. (1994) \\
\hline 3. & C organic $(\%)$ & C organik** & Sulaiman et al. (2005) \\
\hline 4. & N Total (\%) & Kjeldahl & - \\
\hline 5. & $\mathrm{C} / \mathrm{N}$ rasio & - & - \\
\hline 6. & P Olsen $\left(\mathrm{mg} \mathrm{kg}^{-1}\right)$ & spektrofotometer** & Sulaiman et al. (2005) \\
\hline 7. & KTK (me/100 g) & $\mathrm{NH}_{4} \mathrm{OAC}$ pH: $71 \mathrm{~N}^{*}$ & Sulaiman et al. (2005) \\
\hline 8. & $\mathrm{NH}_{4}\left(\mathrm{mg} \mathrm{kg}^{-1}\right)$ & Kolorimetri* & Jaya et al. (1994) \\
\hline 9. & $\mathrm{NO}_{3}\left(\mathrm{mg} \mathrm{kg}^{-1}\right)$ & Kjeldahl & - \\
\hline \multicolumn{4}{|c|}{ Natural feed } \\
\hline 1. & $\begin{array}{l}\text { Type, composition and } \\
\text { abundance of plankton }\end{array}$ & Microscope ** & $\begin{array}{l}\text { Davis (1955; Ward and Whipple, } \\
\text { 1959; Needham and Needham, } \\
\text { 1969; APHA, 1985) }\end{array}$ \\
\hline
\end{tabular}

